Document downloaded from:

http://hdl.handle.net/10251/64492

This paper must be cited as:

Alonso Guillén, JL.; Segura, M.; Rojo, C.; Rodrigo, MA.; Martín Monerris, M.; Vera García, P. (2015). The role of charophytes in a Mediterranean pond created forrestoration purposes. Aquatic Botany. 120:101-111. doi:10.1016/j.aquabot.2014.05.004.

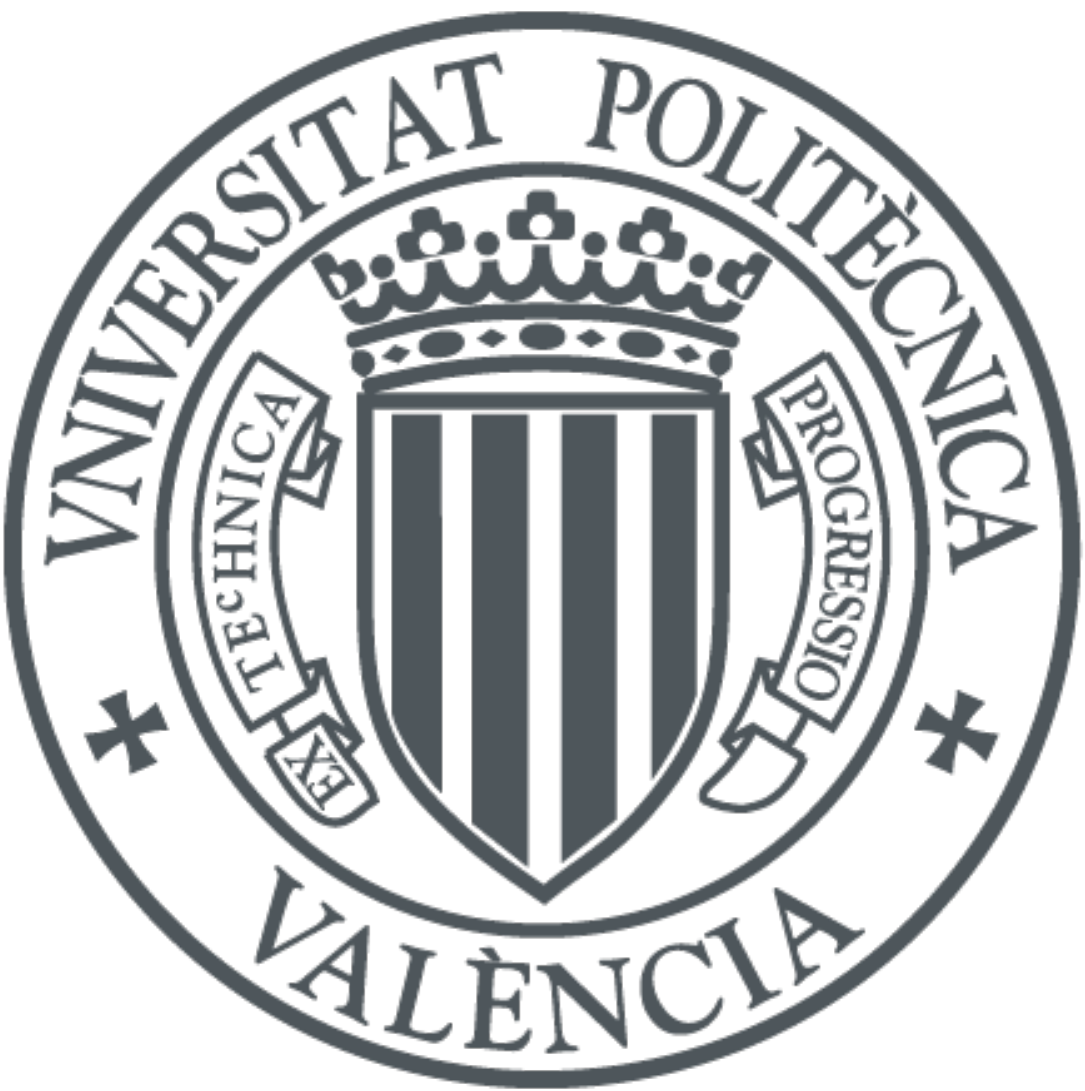

The final publication is available at

http://dx.doi.org/10.1016/j.aquabot.2014.05.004

Copyright Elsevier

Additional Information 


\title{
The role of charophytes in a Mediterranean water spring created for restoration purposes
}

\author{
María A. Rodrigo ${ }^{1 *}$, Carmen Rojo ${ }^{1}$, Matilde Segura ${ }^{1}$, José L. Alonso-Guillén ${ }^{1}$ \\ Miguel Martín ${ }^{2}$ and Pablo Vera ${ }^{3}$
}

\footnotetext{
${ }^{1}$ Integrative Ecology Group. Cavanilles Institute for Biodiversity and Evolutionary Biology, University of Valencia, Valencia, Spain.

${ }^{2}$ Instituto de Ingeniería del Agua y Medio Ambiente, Universitat Politècnica de València, Cno. de Vera s/n, Valencia, Spain.

${ }^{3}$ Sociedad Española de Ornitología (SEO/BirdLife). Delegación de la Comunidad Valenciana. c/ Tavernes Blanques 29, 46120 Alboraia, Valencia, Spain.
}

*Corresponding author: maria.a.rodrigo@uv.es

\section{Highlights}

1. A spring was created to increase local charophyte diversity in a Natural Park.

2. Five species grew from sediment oospores; C. hispida was dominant.

3. The charophyte meadow played a key role in the maintenance of clear-water phases.

4. Nutrient competition and allelopathy primarily caused low microalgal numbers.

5. Some factors threaten charophyte growth, but the restoration plan was successful. 


\section{Abstract}

A small, shallow basin was created and flooded with groundwater in a Reserve Area in Albufera de Valencia Natural Park (AVNP) under the scope of a restoration program. The goal was to mimic typical environments such as freshwater springs, abundant in AVNP in the past but currently suffering from deterioration. The final objective was to increase the local biodiversity of submerged macrophytes, particularly charophytes. From April 2009 (a few months after flooding) to September 2012, the dynamics of charophyte growth and related physical, chemical and biotic factors were followed. Just after flooding, five charophyte species grew spontaneously when oospores germinated in the sediments. C. hispida populations largely dominated the community and developed dense meadows that covered virtually the entire bottom. Charophytes exerted a clear negative influence on microalgal densities (through nutrient competition and allelopathy), increasing water transparency. C. hispida stands precipitated substantial $\mathrm{CaCO}_{3}$ in the form of encrustations on the plants, accompanied by coprecipitation of inorganic phosphorus, maintaining low concentrations of soluble $P$ in the water. Reduced groundwater inflow, increased salinity, increased nutrient concentration, increased turbidity and increased feeding pressure by waterfowl, separately or by negative synergistic effects, considerably reduced charophyte development during the final year of the study. Despite the charophyte decrease, the stoneworts in this newly created water spring represent one of the most extensive and dense stands of submerged vegetation within AVNP, verifying the achievement of one of the goals of the restoration plan.

Keywords: Chara hispida meadow, Nitella hyalina, restoration, sediment bank, charophyte-microalgal interaction, zooplankton, herbivore pressure. 


\section{Introduction}

Charophytes are a component of submerged vegetation. They are of considerable interest due to the numerous beneficial roles they perform (Coops, 2002; Kufel and Kufel, 2002). However, charophytes remain severely threatened (Lambert and Davy, 2011; del Pozo et al., 2011; Auderset Joye and Schwarzer, 2012; Baastrup-Spohr et al., 2013). In semi-arid areas, such as the coast of the Mediterranean, the habitat has deteriorated severely (Parcerisas et al., 2012). In these zones, where large and deep water bodies are scarce, the wetlands with their lagoons, coastal ponds and shallow and small water bodies represent essential aquatic ecosystems for the development of charophytes (Martínez-Taberner and Moyà,1991; Alonso-Guillén, 2011). Albufera de València Natural Park (AVNP), a protected area of 21,000 ha that includes the largest lagoon (3,500 ha) on the Iberian peninsula, an area of 14,000 ha devoted to rice fields, several shallow water bodies in inter-dunal depressions and groundwater springs, is likewise threatened. The main lagoon, largely covered by charophytes in the past (Rodrigo et al., 2010) is currently hypertrophic and has no submerged vegetation. The water springs in AVNP, formerly abundant, have deteriorated (due, e.g., to desiccation and pollution, Soria, 1992). The richness of charophytes in the area has been severely reduced. The authorities have sought to allow the charophyte diversity to recover by restoring the affected springs, but the charophyte richness has not yet recovered. Seven water springs in the Natural Park were examined, but charophytes (only two species, Chara vulgaris L. and Nitella hyalina (De Candolle) C. Agardh) could be detected sporadically in only two of these springs (Alonso-Guillén, 2011). Within a Reserve Area (Tancat de la Pipa) in AVNP and under the scope of a broader restoration program (Rodrigo et al., 2013a, b), a small, shallow basin was created in 2008 and flooded with subterranean waters in an attempt to mimic the typical springs in the area, with the final goal of increasing the area's charophyte richness. The recent creation of this body of water furnishes a perfect scenario for investigating (i) whether 
the charophyte diversity has increased in the area of the Natural Park but also (ii) whether charophytes are able to colonise and grow in the newly created water spring as a result of the germination of propagules in the sediment bank and, consequently, (iii) the ecological role of the charophytes in the trophic status of this new ecosystem. We studied the propagules in the sediment bank and followed the dynamics of charophytes for the four years since the creation of the new water body, and we monitored the time course followed by selected physical, chemical and biological factors. The relationships between charophytes (as submerged macrophytes) and microalgae include a set of known mechanisms, such as competition for inorganic nutrients (Mulderij et al., 2007), allelopathy in both directions (van Donk and van de Bund, 2002; Pflugmacher, 2002), light limitation (Scheffer et al., 1993; Arthaud et al., 2012) and the consequence of shifts in both the size structure and functional roles of the plankton (Bakker et al., 2013), e.g., a decrease in non-edible cyanobacterial filaments (Rojo et al., 2013). Moreover, macrophyte beds offer zooplankton a refuge from fish predation (Burks et al., 2002; Carpenter et al.,1985). In turn, large herbivorous crustaceans feeding on microalgae can help maintain water clarity (Blindow et al., 2000, 2002), although this is not always the case (Compte et al., 2011). For this reason, we also studied the relationship between charophyte development and plankton community structure to determine whether these macrophytes, via controlling effects on the plankton, are involved with water transparency in a positive feedback process. Another biotic factor considered was the pressure on the charophyte stands exerted by herbivorous waterfowl. We discuss the possible mechanisms that maintain the clear-water state as well as the possible reasons for the changes in vegetation observed at the end of the study period. 


\section{Materials and methods}

\subsection{Study site}

The artificial water spring is located within the Tancat de la Pipa Reserve Area (AVNP; $39^{\circ} 21^{\prime} 57^{\prime \prime} \mathrm{N}, 0^{\circ} 20^{\prime} 55^{\prime \prime} \mathrm{W}$; Fig. 1A), a 40 ha zone formerly devoted to rice crops (Rodrigo et al., 2013a). After the construction of the basin, it was fed by groundwater sources via a deep artesian well. It has a surface area of approximately 4 ha and mean and maximum depths of $0.9 \mathrm{~m}$ and $2.2 \mathrm{~m}$, respectively. The groundwater inflow is located in the northwest part of the basin, and there is an outlet in the southwest part (Fig. 1A). Initially, the inflow was approximately $4 \mathrm{I} \mathrm{s}^{-1}$, but the inflow later gradually decreased. The flow stopped entirely in January 2012 (Fig. 1B). The artesian well was rebuilt, and the groundwater inflow was re-established one month later to values similar to those at the beginning of the project. The water spring has hard water with a bicarbonate concentration of $160 \pm 4 \mathrm{mg} \mathrm{l}^{-1}$ (annual mean \pm standard deviation). Just after flooding, several cultures of Myriophyllum spicatum L. were planted in the water spring by the managers.

\subsection{Charophyte sampling and analyses}

To assess the potential contribution of the seed bank in the sediments in the new basin as a source of future vegetation development through germination, two sediment cores (length $10 \mathrm{~cm}$, diameter $6 \mathrm{~cm}$ ) were taken to search for charophyte fructifications at the end of 2008 after flooding by the managers. The sediment was extracted from the tube and homogenised, and an aliquot was taken to determine the sediment water content immediately after sampling. The remaining sediment was washed sequentially with tap water and sieved (mesh sizes 1000, 500 and $250 \mu \mathrm{m}$ ) (Rodrigo et al., 2010). The three fractions obtained after sieving were observed using a stereomicroscope. The charophyte remains (3,900 fructifications isolated and identified) consisted of oospores and gyrogonites (calcified oospores). Gyrogonites and oospores were removed with a 
brush and/or forceps, identified and separated by species. Four fructification types ("apparently viable" and non-viable oospores and gyrogonites) were distinguished. Apparently viable oospores were defined as intact, hard oospores that did not undergo deformation when pressed with the forceps and contained "healthy" starch granules (de Winton et al., 2004; Rodrigo et al., 2010). Apparently viable gyrogonites were defined by the presence of an intact calcium carbonate cover. The four fructification types were counted, and the relative frequencies per gram sediment dry weight were calculated.

The first survey to assess charophyte richness was performed in March 2009, a few months after flooding. Charophyte biomass per surface unit was determined bimonthly thereafter from April 2009 to September 2012 at three sampling stations (Fig. 1A). Charophyte thalli from $0.034 \mathrm{~m}^{2}$ quadrats were harvested, washed in water to eliminate residues of sediment and epiphytic algae and dried at $70{ }^{\circ} \mathrm{C}$. The dried biomass from each sample was weighed to obtain dry weight. The carbonate content of the charophyte incrustations was determined as the difference in dry weight before and after washing the charophytes with an $\mathrm{HCl}$ solution to remove the incrustations. This procedure was adapted from the method described in Kufel et al. (2013). The results of this method did not significantly differ from those of the loss-of-ignition method (Heiri et al., 2001) (unpublished results). The carbonate content was determined from the whole-charophyte sample used for measurment of the dry weight and, in several individuals, from the differentiated apical and basal parts of the plant.

Four vegetation maps were developed during the summers of 2009-2012. The boundary of the water spring was determined on foot by recording the coordinates at intervals of $4 \mathrm{~m}$ using a global positioning system (GPS, Garmin, Etrex, Kansas City, USA). Twenty-two radial transects across the spring were made on each occasion. Coordinates and water depths were recorded at intervals of $3 \mathrm{~m}$. Submerged vegetation patches and helophyte cover were also located. Each group of coordinates 
was analysed using the GIS free software programme gvSIG 1.9 to represent vegetation locations and area cover. The total biomass was calculated from the area cover and the mean biomass per unit surface area for the corresponding sampling months.

\subsection{Water level and flow measurements}

Water level fluctuations were recorded weekly by the managers of the area from readings on a graduated pole set up in the northern part of the water spring. The fluctuations indicated in figure 1B are expressed relative to depth zero on the day the pole was installed. Groundwater flow was measured with a continuously registering flow meter installed by the managers in the water spring in August 2009.

\subsection{Sampling and analyses of water and determination of the underwater light climate} Physical and chemical variables were measured and water samples taken monthly from April 2009 to September 2012 at approximately 13:00 from a boat positioned close to the centre of the water spring (Fig. 1A). The water temperature, the dissolved oxygen concentration (DO), the conductivity/salinity and the $\mathrm{pH}$ were measured in situ using portable field measurement equipment (WTW® probes). Depth profiles of light penetration were determined by measuring in situ subaquatic irradiance with a $Q$ $32010 \mathrm{Li}-$ Cor quantum spherical sensor connected to a Li-Cor 250 meter at $10 \mathrm{~cm}$ intervals at the deepest part of the water spring. These measurements were made from the boat. The boat was held in position with a rope that was tied to the boat and to two points on the shore of the spring. Secchi depth measurements were also recorded. Water samples for chemical and biological analysis were collected with a jar $10 \mathrm{~cm}$ below the water surface and kept in cool and dark conditions prior to analysis. The concentrations of total suspended solids, total phosphorus (TP), total nitrogen (TN), nitrate, nitrite, ammonium and silicate and the values of turbidity and chemical oxygen 
demand were determined using standard methods (as described in Martín et al., 2013 and Rodrigo et al., 2013b). The Chl a concentration was calculated following the method described in Rodrigo et al. 2013b. Phytoplankton samples were preserved in $250 \mathrm{ml} \mathrm{PVC} \mathrm{bottles} \mathrm{and} \mathrm{fixed} \mathrm{immediately} \mathrm{with} \mathrm{iodine-Lugol} \mathrm{solution.} \mathrm{Metazooplankton}$ (rotifers, cladocerans and copepods) was collected by filtering up to $5 \mathrm{I}$ of water through $37 \mu \mathrm{m}$ Nytal mesh. Each sample was fixed immediately with sucrose-formalin (Haney and Hall 1973). The phytoplankton and metazooplankton determinations were performed following Rojo et al. (2012).

\subsection{Determination of waterfowl abundance}

The abundance of ducks and coots was determined by counts. Censuses were conducted at fortnightly intervals with a telescope, always within the first three hours after dawn.

\subsection{Statistical analyses}

The normality of the distributions of the variables analysed and the homeoscedasticity of the samples were tested with Kolmogorov-Smirnov and Levene tests, respectively. If both conditions were satisfied, a one-way ANOVA and a post hoc Bonferroni analysis were used to compare the means of the variables. Otherwise, non-parametric tests were used. The relationships between Chl a concentration and Secchi disc measurements and the light extinction coefficient were analysed using linear estimation.

Correlations between variables were calculated on transformed data: physical and chemical variables were log-transformed except $\mathrm{pH}$ and the percentages (e.g., \%DO), and variables referring to the biotic community were square root transformed. A crosscorrelation analysis was used because it allows lagged effects to be detected; many ecological relationships are commonly delayed in the plankton community (Reynolds, 
1997), and this procedure has proved to be a fruitful approach to reveal such timelagged effects (Álvarez-Cobelas et al., 2006). All statistical analyses were carried out with SPSS version 19.0.0 computational software.

\section{Results and Discussion}

The fructifications in the sediment bank surveyed immediately after the flooding of the spring by the managers belonged to 11 species of charophytes: Chara aspera C.L.Willdenow, C. baltica A.Bruzelius, C. braunii C.C.Gmelin, C. globularis J.L.Thuiller, C. hispida L., C. vulgaris L., Chara sp. (an unusual fructification morphotype; Rodrigo et al., 2010), Lamprothamnium papulosum (K.Wallroth) J.Groves, Nitella hyalina (De Candolle) C.Agardh, Tolypella glomerata (Desvaux) Leonhardi and T. prolifera (Ziz ex A.Braun) Leonhardi. The fructifications of T. glomerata were the most abundant (69\%; Fig. 2A), although the numbers of apparently viable oospores were low (3\%; Fig. 2B). The fructifications of $C$. hispida represented only $1 \%$ of the total; however $34 \%$ of these fructifications appeared to be viable. The viability of the charophyte fructifications was verified based on the observed germination of several species in the water spring. The procedures used to transform former rice fields in the current Reserve Area (e.g., the construction of the basin using machinery) caused the sediments to be disturbed. The area occupied by these rice fields was previously the Albufera de València lagoon (AV lagoon hereafter). Deep sediments corresponding to the saline period of the AV lagoon's history (Rodrigo et al., 2010) were moved upwards as a result of the construction project. Due to this movement, the surficial sediments were found to contain fructifications formed by species that are characteristic of fluctuating and high saline conditions, e.g., L. papulosum (Soulié-Märsche, 1998). Previous studies on the viability of charophyte fructifications have shown that oospores as old as 60 years buried in the AV lagoon sediments can germinate (Rodrigo et al., 2010); this finding was confirmed in the present study. The presence of $C$. braunii fructifications in the 
spring sediments is explained by the previous use of the area as a rice field, a type of habitat in which this species is common (Alonso-Guillén, 2011). In March 2009, a few months after flooding, five species (C. hispida, C. aspera, $C$. vulgaris, $N$. hyalina and $T$. glomerata) grew spontaneously in the spring as a result of the germination of the fructifications in the sediments. Thus, of the seven species found in the sediment bank (not including species from saline environments) whose fructifications could potentially germinate in the current environmental conditions of the water spring, five different species (a high proportion) germinated. T. glomerata appeared and covered the shores during the cool period. $C$. vulgaris and $C$. aspera did not increase their distribution, and neither did the planted M. spicatum. Instead, C. hispida was the dominant charophyte. It had already developed a dense and permanent monospecific stand a few months later. This is an example of how charophytes can outcompete tall-growing angiosperms such as $M$. spicatum under low phosphorus supply and high water-clarity (Richter and Gross, 2013). Charophytes have been described to have more efficient nutrient uptake systems at low nutrient availability (Bakker et al., 2010; Wuestenberg et al., 2011), allowing them to outcompete angiosperms. $N$. hyalina occupied small areas in the water spring, primarily within the emergent vegetation in the shallower areas of the spring (Fig. 3A). It reached its maximum biomass in July 2010, $0.7 \mathrm{Kg} \mathrm{DW} \mathrm{m}^{-2}$. The environmental conditions that allowed the development of $C$. hispida in the water spring were fluctuating and not wholly cyclic throughout the study period, as observed in similar ecosystems (Rojo and Rodrigo, 2010; Rojo et al., 2012) that are subjected to disturbances such as the lack of water input during the winter of 2011-12 (Fig. 1B). However, the water level fluctuations (considering the maximum and the lowest level throughout the study) resulting from variations in inflow, outflow, evaporation and rainfall were only approximately $20 \mathrm{~cm}$ in magnitude (Fig. 1B). The water spring exhibited strong fluctuations in water temperature with the annual cycle, as found in Mediterranean latitudes (Fig. 4A). The $\mathrm{pH}$ of the water remained highly constant 
through time, ranging from 7.0 to 8.2 . However, salinity tripled, changing from 1.3 to 4.1 $\mathrm{g} \mathrm{I}^{-1}$ (Fig. 4B). The salinity increase is related to the variation in the underground water supply (Fig. 1B) $(r=0.89 ; p=0.003$ for 2001 , when the principal salinity increase was observed). Orthophosphate concentrations were always below $0.005 \mathrm{mg} \mathrm{Pl}^{-1}$; however, TP ranged from 0.005 to $0.09 \mathrm{mg} \mathrm{Pl}^{-1}$, with the highest concentrations occurring in April 2012. The ammonium and nitrate concentration ranged from 0.01$0.21 \mathrm{mg} \mathrm{N} \mathrm{I}^{-1}$ and $0.1-1.0 \mathrm{mg} \mathrm{N} \mathrm{I}^{-1}$, respectively. The $\mathrm{TN}$ concentration varied between 0.1 and $2.1 \mathrm{mg} \mathrm{N} \mathrm{I}^{-1}$ (Fig. 4C). Overall, the values of all nutrient concentrations were higher beginning at the end of 2011. The underwater light climate varied substantially, as indicated by the range of Secchi disc (SD) depths from $0.5 \mathrm{~m}$ to $1.75 \mathrm{~m}$ (the latter value corresponding with the bottom of the water spring, where the SD depth was measured (Fig. 4D)), Even in deeper parts of the spring, however, the bottom could be observed in the springtime. The photosynthetically active radiation (PAR) at the mean depth of the water spring $(0.9 \mathrm{~m})$ ranged over one order of magnitude, from a maximum of $1230 \mu \mathrm{mol}$ photons $\mathrm{m}^{-2} \mathrm{~s}^{-1}$ (60\% of incident light) in July 2010 (sunny day), when the maximum charophyte biomass was measured, to $130 \mu \mathrm{mol}$ photons $\mathrm{m}^{-2} \mathrm{~s}^{-1}$ (25\% of incident light) in February 2012 (cloudy conditions). During most of the first two years, the PAR reaching a depth of $1.5 \mathrm{~m}$ (most of the spring was shallower than 1.5 $\mathrm{m}$ ) was greater than $175 \mu \mathrm{mol}$ photons $\mathrm{m}^{-2} \mathrm{~s}^{-1}$ (over 2 mol photons $\mathrm{m}^{-2} \mathrm{~d}^{-1}$ ), which facilitated both germination and vegetative growth for the establishment of $C$. hispida (De Winton et al., 2004).

No variation in the $C$. hispida biomass per unit surface area was found among the three sampling sites within the $C$. hispida bed; the ANOVA found no statistically significant differences in the annual means. For this reason, we will use the spatial mean values from the three sites in the remainder of this paper. The maximal length observed for individuals of $C$. hispida was $1.15 \mathrm{~m}$. During most of the year, the apical parts of these plants were at the surface (Fig. 3B). The $C$. hispida biomass per unit surface area 
described an annual pattern, with the growth period beginning in early spring and senescence at the end of summer (Figs. 4A-5A), although the meadows overwintered. Maximum biomass increased together with the coverage and was as high as $2.3 \pm 0.7$ Kg DW m² in July 2010 (Figs. 4A-5A); the minimum values occurred in April 2012, substantially less than $0.5 \mathrm{Kg} \mathrm{DW} \mathrm{m}^{-2}$ (Fig. 5A). The annual mean biomass of $C$. hispida in 2010 was higher than that measured for the same species in a deeper transparent lake in Spain (Rodrigo et al., 2007) and of the same order of magnitude as that found in other shallow lakes possessing abundant charophyte vegetation (Pukacz et al., 2013). C. hispida coverage changed from more than 3,000 Kg DW in summer 2009 to a maximum of greater than $12,000 \mathrm{Kg} \mathrm{DW}$ in 2010 and decreased to less than 2,000 Kg DW in June 2012 (Table 1).

During the first three annual cycles (2009 to 2011), C. hispida followed the pattern described above. Growth began when temperatures were still low $\left(12-16^{\circ} \mathrm{C}\right)$ and decreased when the temperatures became high (approximately $30^{\circ} \mathrm{C}$ ). The periodical dynamics of temperature and Chara growth showed a two-month lag $(r=-0.50, p=$ 0.006 , lag = 2); as stated above, the dynamics were different beginning in 2011 . The temperature was higher in winter, and the lagged covariation between temperature and Chara growth was no longer observed (Fig. 4A). The salinity (Fig. 4B), which had fluctuated slightly from 2009 until the end of 2011, was substantially higher beginning at the end of 2011, and this change could also have affected the freshwater species $C$. hispida. Typical freshwater species of the genus Chara are able to regulate their turgor for a salinity range up to a certain threshold. In $C$. vulgaris, this threshold may be as much as $6 \mathrm{~g} \mathrm{l}^{-1}$ (Winter and Kirst, 1991). Species of the genus Nitella appear not to regulate turgor. Hence, $N$. hyalina could also have been affected by the increase in salinity in the water spring; however the release of competition with $C$. hispida due to its coverage decline (Fig. 3A) might explain the increase of $N$. hyalina coverage 
observed in 2012. The results for inorganic nutrients showed that the highest measured concentrations of $\mathrm{P}$ and $\mathrm{N}$ coincided with less charophyte development; is this high level of $\mathrm{P}$ and $\mathrm{N}$ a cause of the charophyte decline or, alternatively, its consequence? The release of organic and inorganic nutrients has been considered a consequence of the senescence of submerged plant communities (Thorén et al., 2004; Rodrigo et al., 2007). In 2009-2011, however, during the autumn decay of the $C$. hispida meadow, the nutrient concentrations did not increase in a way that would be relevant to this hypothesis. The nutrient concentrations only increased significantly during 2012 , coinciding with the hydrological disturbance previously mentioned (Fig. 1B). It is probable that the increase in compounds such as ammonium, the only compound with a statistically verified inverse relationship with $C$. hispida biomass $(r=-0.46, p=0.013$, lag=2), was damaging to the charophytes. Ammonium concentrations exceeded the threshold considered toxic for some macrophyte species $\left(0.14 \mathrm{mg} \mathrm{N}^{-1}\right.$; Smolders et al., 1996) only in 2012, particularly in May and August. Nitrate has also been described as producing the greatest detrimental effect on charophyte occurrence in the field (Lambert et al., 2011). Certain species can be inhibited if they are exposed to nitrate concentrations greater than extremely low values. The nitrate concentrations in the water spring from the end of 2011 and 2012, although they were the highest values observed, were far less than the critical limit of $2 \mathrm{mg} \mathrm{l}^{-1}$ (mean annual average) described by Lambert et al. (2011) as necessary to protect charophytes within wetland ecosystems. Therefore, the increment in nutrient concentrations might be both a consequence of the uptake of fewer nutrients by the lower biomass of charophytes and a cause for the decline of the charophytes.

Another resource related to $C$. hispida growth dynamics is light availability (de Winton et al., 2004; Schneider et al., 2006), which is related to the shadow effect of the seston. This relationship is likewise complex (van Donk and van de Bund, 2002). The dynamics of the phytoplankton explained $70 \%(p<0.0001)$ of the variation in the $\mathrm{Chl} a$ 
concentration (Fig. 5A), and it was also related to the level of suspended solids $(r=0.78$, $\mathrm{p}<0.0001)$. Sestonic Chl a was inversely and significantly correlated with water transparency (Fig. 6).

Phytoplankton biomass ranged from 0.1 to $154 \mathrm{~mm}^{3} \mathrm{I}^{-1}$ and $\mathrm{Chl}$ a from 0.5 to $46 \mu \mathrm{g} \mathrm{I}^{-1}$ (Fig. 5A and B). During the first summer (2009), phytoplankton biomass corresponded to eutrophic water conditions (Willén, 2000), and the ecological status of the spring according to the Water Framework Directive guidelines (WFD, 2000; CEDEX, 2010), based on phytoplankton and other metrics involving aquatic flora, was "poor". However, its ecological status improved to "moderate" in 2010, favoured by the development of the charophyte stands. Microalgal biomass was related to suspended solids and turbidity ( $r=0.61, p<0.0001$ and $r=0.69, p<0.0001$, respectively) and to TN and TP $(r=0.45$ and $r=0.57$, respectively, $p<0.0001)$. Overall, microalgal biomass was shared by the different phytoplankton taxonomic groups. However, when phytoplankton biomass was high (Fig. 5B), filamentous cyanobacteria (Planktolyngbia sp., Geitlerinema sp., Pseudanabaena sp.) were the principal contributors. As a result, the proportion of the phytoplankton variance explained by the cyanobacteria was high $(\mathrm{r}=0.95, \mathrm{p}<0.00001)$. A lagged and inverse relationship was found between $C$. hispida growth and phytoplankton biomass $(r=-0.42, p=0.01$, lag=2; Fig. 5A-B). Cyanobacteria grew when the Chara beds started to decline $(r=-0.43, p=0.008$, lag $=2)$. This inverse relationship is relevant because filamentous cyanobacteria are unmatched competitors in low light and also represent a photoautotrophic group that can produce exceptionally high turbidity per unit phosphorus (Scheffer et al., 1997), hampering the growth of charophytes. Moreover, charophytes and microalgae can affect each other through competition via inorganic nutrients and/or allelopathy. Charophytes have been described as a nutrient sink (Kufel and Kufel, 2002), particularly for nitrogen (Rodrigo et al., 2007). Their $\mathrm{N}$ uptake is very efficient, and they remove this nutrient from the water column (Rodrigo and Alonso-Guillén, 2008). Charophytes are also known to affect 
phosphorus cycling by direct uptake and by deposition of calcium carbonate in the form of encrustations on the tissues, accompanied by coprecipitation of inorganic $P$ (Pelechaty et al., 2013; Puckaz et al., 2013; Kufel et al., 2013). Charophytes from this water spring also precipitated large amounts of calcium carbonate, with an annual mean of $30 \%( \pm 15 \%$ SD) of the DW for C. hispida and $21 \pm 9 \%$ for $N$. hyalina. The proportion of $\mathrm{CaCO}_{3}$ on charophytes increased from the cool to the warm season, reaching a value near $55 \%$ at certain times (June). However, no statistically significant differences were found between the apical portions (new tissue) and the basal portions (old tissue) of the same individual. Clearly, coprecipitation may have contributed to maintain low soluble $\mathrm{P}$ concentrations, always $<0.005 \mathrm{mg} \mathrm{l}^{-1}$, in the water spring (Kufel et al., 2013). The clear negative influence exerted by $C$. hispida on microalgal densities can also be related to infochemical interactions (Hilt and Gross, 2008). C. hispida collected from this water spring is the macrophyte species (in comparison to $M$. spicatum and $N$. hyalina) with the strongest allelopathic effect on natural assemblages of microalgae and particularly on cyanobacteria, as recently demonstrated in laboratory experiments (Rojo et al., 2013).

The dynamics of the zooplankton (Fig. 5C) showed several peaks. In some cases, these peaks were due to the development of small herbivorous rotifers. In others, they were due to large crustaceans, particularly copepods (Acanthocyclops americanus Sars, Eucyclops albuferensis Alekseev), which are omnivorous and consume rotifers efficiently (Nandini and Sarma, 2007; Enríquez et al., 2011). The alternation of these peaks is the reason that the total zooplankton dynamics was not explained by any of the variables considered, either environmental conditions or the dynamics of other aquatic groups. However, the separate analysis of the dynamics of the zooplankton for each group showed that the initiation of rotifer growth coincided with the greatest growth of the $C$. hispida beds. The maximum rotifer biomass was attained when $C$. hispida was already declining (Fig. $5 \mathrm{C} ; \mathrm{r}=-0.35, \mathrm{p}=0.01$, lag=2); thereafter, the rotifers 
also declined rapidly, and peaks of cyanobacteria (not edible by rotifers) were observed together with the peaks of the copepods that fed on rotifers. For this reason, crustaceans showed an inverse relationship with charophyte biomass (Fig. 5A-C; $r=-$ $0.42, p=0.007)$.

Other biotic factors related to the decline of the submerged vegetation were the feeding activities of herbivorous fish and birds (Krupska et al., 2012; Noorduis et al., 2002). The fish community in this water spring is primarily dominated by mosquitofish (Gambusia holbrooki Girard), a small cyprinodont exotic species that is planktivorous. For this reason, a direct influence on charophyte meadows is not expected. The predatory activity of mosquitofish could be the cause of the low abundance of large cladocerans such as Daphnia spp. observed in the water spring (Compte et al., 2011). However, although its abundance was not quantified, the exotic red swamp crayfish Procambarus clarkii Girard was common in the charophyte beds. Because this crayfish species has been found to feed preferentially on charophytes rather than higher plants (Cirujano et al., 2004), it might also have contributed to the charophyte decline. Grazing by herbivorous waterfowl is also known to cause significant disturbances to submerged vegetation (Matuszak et al., 2012). Up to eight species of Anatidae are found in the area of Tancat de la Pipa, but the mallard (Anas platyrhynchos L.) is the most abundant. Among coots, the Eurasian coot (Fulica atra L.) is the most abundant. Herbivorous waterfowl visited the water spring. The maximum numbers attained by these herbivores were 31 ducks and 63 coots per day of observation in 2011 and 2012, respectively (Fig. 5D). AVNP includes a large area of flooded ecosystems (the rice fields; 14,000 ha) in which waterfowl find food. However, during the portion of the rice crop cycle (from mid-February to mid-May) when the fields are dry, only small areas of flooded habitats in the Park have submerged vegetation, and the birds become concentrated in these areas. Tancat de la Pipa is one such area and is, therefore, subjected to greatly increased grazing pressure. The higher abundance of coots and 
ducks in 2012 was related to the disappearance of the submerged vegetation in the two adjacent shallow lagoons in the area (Fig. 1A; Rodrigo et al., 2013a, b) where the birds primarily concentrated during 2009-2010, feeding chiefly on M. spicatum., During summer 2012, moreover, there were clearly visible signs that the apical parts of the $C$. hispida individuals in the water spring had been eaten by birds. Both ducks and coots could easily have reached the charophyte stand, dabbling or foraging when the vegetation was near the surface of the water. Additionally, the coots could have dived to feed on deeper stands (Fig. 1B). Moreover, the denser population of waterfowl in the water spring during the final portion of the study would have created an additional nutrient supply due to the production of faeces (Matuszak et al., 2012).

\section{Conclusions}

Despite the decrease in charophyte coverage and biomass per surface unit in the last year in the newly created water body, the stoneworts in this water spring constitute an "island" of charophyte diversity in a "sea" of eutrophised waters because the spring still represents one of the most extensive and dense stands of submerged vegetation within AVNP. Accordingly, one of the goals of the restoration plan has been achieved. Moreover, the charophyte community in the water spring has provided ecological services because it has procured stocks for use as founder colonies in the revegetation of the two small shallow lagoons of the same Reserve Area, which are under restoration (Rodrigo et al., 2013a).

The $C$. hispida meadow played a key role in the maintenance of a clear-water phase during the study period in this new aquatic habitat, as it was responsible for maintaining low abundances of phytoplankton. The positive feedback mechanisms linking the charophytes to the water transparency stabilised this clear-water state, particularly during the second year, and also improved the trophic status of the water spring. Temperature was the principal driver of charophyte growth and senescence; when the 
meadows declined, the phytoplankton community was dominated primarily by nonedible cyanobacteria in autumn, most likely due to the decrease in allelopathic activity of the senescent charophytes and shifts in zooplankton community composition. Charophytes did not provide shelter to large cladocerans because abundant small planktivorous fish could enter the vegetation and feed on the cladocerans. Many ecological factors important to the development of charophytes changed simultaneously during the final period of the first four years of "life" of this new habitat: 1) reduced groundwater inflow, 2) increased salinity, 3) increased nutrient concentration, 4) increased turbidity and 5) increased herbivore pressure by waterfowl. It is certain that all these factors acted together to affect the $C$. hispida stands negatively. Because biotic-abiotic relationships in charophyte beds are very intricate (van Donk and van de Bund, 2002), it remains to determine which of these factors is the chief cause or if negative synergistic processes are involved. Additional research to analyse the assumed processes more precisely is already planned.

\section{Acknowledgements}

The authors express thanks for the funding of this study by TRAGSA and Confederación Hidrográfica del Júcar (J. Ferrer, T. Estrela, M. Regidor) and by the Spanish Ministry of Economy and Competitiveness (research project CGL2009-10292, including plan E). We also thank Fidel Rubio, Jara García-Chicote, Fran Cortés, Sara Calero and William Colom for their help during field and laboratory work. We also thank Matthieu Lassalle and Lucía Moreno (Tancat de la Pipa staff), particularly for providing data on inflows and water depth. We are grateful for the collaboration of the other members of the research group from Instituto de Ingeniería del Agua y Medio Ambiente (Polytechnic University of Valencia) and of Mario Giménez from SEO/Birdlife. The waterfowl censuses were part of the SEO/BirdLife's Bird Monitoring Program in AVNP, supported by the Alas sobre Agua Project and with the valuable help of many 
volunteers. Joan M. Benavent facilitated the aerial photography of the water spring.

American Journal Experts carefully reviewed the English language of the manuscript.

\section{References}

Alonso-Guillén, J.L., 2011 Charophytes in restoration of aquatic ecosystems. A study case within Albufera de València Natural Park. PhD Thesis. Universitat de València. Spain.

Álvarez-Cobelas, M. Rojo, C. Velasco J.L., Baltanás, A., 2006. Factors controlling planktonic size spectral responses to autumnal circulation in a Mediterranean lake. Freshwater Biol. 51, 131-143.

Arthaud F., Mousset, M., Vallod, D., Robin, J.L., Wezel, A., Bornette, G., 2012. Effect of light stress from phytoplankton on the relationship between aquatic vegetation and the propagule bank in shallow lakes. Freshwater Biol. 57, 666-675.

Auderset Joye, D., Schwarzer, A., 2012. Liste Rouge characées. Espèces menacées en Suisse. Etat-2010. Office fédéral de l'environnement, Berne ; Laboratoire d'écologie et de biologie aquatique,-Université de Genève, Genève. L'environnement pratique no 1113: 72 pp.

Baastrup-Spohr, L., Lønsmann Iversen, L., Dahl-Nielsen, J., Sand-Jensen, K., 2013. Seventy years of changes in the abundance of Danish Charophytes. Freshwater Biol. doi:10.1111/fwb.12159.

Bakker, E.S., van Donk E., Declerck, S.A.J., Helmsing, N.R., Hidding, B.,Nolet, B.A., 2010. Effect of macrophyte community composition and nutrient enrichment on plant biomass and algal blooms. Basic Appl. Ecol. 11, 432-439.

Bakker, E.S., Sarneel, J.M., Gulati, R.D., Liu, Z., van Donk, E., 2013. Restoring macrophyte diversity in shallow temperate lakes: biotic versus abiotic constraints. Hydrobiologia 710, 23-37. 
Blindow, I., Hargeby, A., Wagner, B.M.A., Andersson, G., 2000. How important is the crustacean plankton for the maintenance of water clarity in shallow lakes with abundant submerged vegetation? Freshwater Biol. 44, 185-19.

Blindow,I, Hargeby, A., Andersson, G., 2002. Seasonal changes of mechanisms maintaining clear water in a shallow lake with abundant Chara vegetation. Aquat. Bot. 72, 315-334

Burks, R.L., Lodge, D.M., Jeppesen, E., Lauridsen, T.L., 2002. Diel horizontal migration of zooplankton: costs and benefits of inhabiting the littoral. Freshwater Biol. 47, 343-365.

Carpenter, S.R., Kitchell, J.F., Hodgson, J.R., 1985. Cascading trophic interactions and lake productivity. Bioscience 35, 634-639.

CEDEX, 2010. Documento técnico "Establecimiento de condiciones de referencia y valores frontera entre clases de estado ecológico en masas de agua de la categoría lago para los elementos de calidad "composición, abundancia y biomasa de fitoplancton" y "composición y abundancia de otro tipo de flora acuática", en aplicación de la Directiva Marco del Agua.

Cirujano, S., Camargo, J.A., Gómez-Cordovés, C., 2004. Feeding preference of the red swamp crayfish Procambarus clarkii (Girard) on living macrophytes in a Spanish wetland. J. Freshwater Ecol. 19, 219-226.

Compte, J., Gascón, S., Quintana, X.D., Boix, D., 2011. Fish effects on benthos and plankton in a Mediterranean salt marsh. J. Exp. Mar. Biol. Ecol. 409, 259-266. Coops, H., 2002. Ecology of charophytes: an introduction. Aquat. Bot. 72, 205-208. de Winton, M.D., Casanova, M.T., Clayton, J.S., 2004. Charophyte germination and establishment under low irradiance. Aquat. Bot. 79, 175-187. 
del Pozo, R., Fernández-Alaez, C., Fernández-Aláez, M., Santiago, N.F., 2011.

Assessment of eutrophication effects on charophytes in Mediterranean ponds (North-Western Spain). Fundam. Appl. Limnol. 178, 257-264.

Enríquez-García, C., Nandini, S., Sarma, S.S.S., 2011. Demographic characteristics of the copepod Acanthocyclops americanus (Sars, 1863) (Copepoda: Cyclopoida) fed mixed algal (Scenedesmus acutus)-rotifer (Brachionus havanaensis) diet. Hydrobiologia 666, 59-69.

Haney, J.F., Hall, D.J., 1973. Sugar-coated Daphnia-preservation technique for Cladocera. Limnol. Oceanogr. 18, 331-333.

Heiri, O., Lotter, A.F., Lemcke, G., 2001. Loss on ignition as a method for estimating organic and carbonate content in sediments: Reproducibility and comparability of results. J.Paleolimnol. 25, 101-110.

Hilt, S., Gross, E.M., 2008. Can allelopathically active submerged macrophytes stabilise clear-water states in shallow eutrophic lakes? Basic Appl. Ecol. 9, 42232.

Krupska, J., Pelechaty, M., Pukacz, A., Ossowski, P., 2012. Effects of grass carp introduction on macrophyte communities in a shallow lake. Oceanol. Hydrobiol. St. $41,35-40$.

Kufel, L., Kufel, I., 2002. Chara beds acting as nutrient sinks in shallow lakes - a review. Aquat. Bot. 72, 249-260.

Kufel, L., Biardzka, E., Strzałek, M., 2013. Calcium carbonate incrustation and phosphorus fractions in five charophyte species. Aquatic Botany in press.

Lambert, S.J., Davy, A.J., 2011. Water quality as a threat to aquatic plants: discriminating between the effects of nitrate, phosphate, boron and heavy metals on charophytes. New Phytol. 189, 1051-1059. 
Martín, M., Oliver, N., Hernández-Crespo, C., Gargallo, S., Regidor, M.C., 2013. The use of free water surface constructed wetland to treat the eutrophicated waters of lake L’Albufera de Valencia (Spain). Ecol. Eng. 50, 52-61.

Martínez-Taberner, A., Moyà, G., 1991. Water chemistry tolerance of Charophytes in a Mediterranean coastal marsh. Nova Hedwigia 52, 113-129.

Matuszak, A., Mörtl, M., Quillfeldt, P., Bauer, H.G., 2012. Exclosure study on the exploitation of macrophytes by summering and moulting waterbirds at Lower Lake Constance. Hydrobiologia 697, 31-44.

Mulderij, G., Van Nesc, E.H., Van Donk, E., 2007. Macrophyte-phytoplankton interactions: The relative importance of allelopathy versus other factors. Ecol. Model. 204, 85-92.

Nandini, S., Sarma, S.S.S., 2007. Effect of algal and animal diets on life history of the freshwater copepod Eucyclops serrulatus (Fischer, 1851). Aquat. Ecol. 41 (1), 75-84.

Noordhuis, R., van der Molen, D.T., van den Berg, M.S., 2002. Response of herbivorous water-birds to the return of Chara in Lake Veluwemeer, The Netherlands. Aquat. Bot. 72, 349-367.

Parcerisas, L., Marull, J., Pino, J., Tello, E., Coll, F., Basnou, C., 2012. Land use changes, landscape ecology and their socioeconomic driving forces in the Spanish Mediterranean coast (El Maresme County, 1850-2005). Environ. Sci. Policy 23, 120-132.

Pelechaty, M., Pukacz, A., Apolinarska, K., Pelechata, A., Siepak, M. 2013. The significance of Chara vegetation in the precipitation of lacustrine calcium carbonate. Sedimentology DOI: 10.1111/set.12020.

Pukacz, A., M. Pełechaty, M., Frankowski., 2013. Abundant charophyte vegetation and carbonate production in a shallow water body. Hydrobiologia in press. 
Pflugmacher, S., 2002. Possible Allelopathic Effects of Cyanotoxins, with Reference to Microcystin-LR, in Aquatic Ecosystems. Environ. Toxicol. 17 (4), 407-413.

Reynolds, C.S., 1997. Vegetation processes in the pelagic: a model for ecosystem theory. Excellence in ecology. Ecology Institute, Oldendorf. 371 pp.

Richter, D., Gross, E.M., 2013. Chara can outcompete Myriophyllum under low phosphorus. Aquat. Sci. 75, 457-467.

Rodrigo, M.A., Rojo, C., Álvarez-Cobelas, M., Cirujano, S., 2007. Chara hispida beds as a sink of nitrogen: evidence from growth, nitrogen uptake and decomposition. Aquat. Bot. 87, 7-14.

Rodrigo, M.A., Alonso-Guillén, J.L., 2008. In situ nitrate uptake rates in two Chara species. Charophytes 1, 49-54.

Rodrigo, M.A., Alonso-Guillén, J.L., Soulié-Märsche, I., 2010. Reconstruction of the former charophyte community out of the fructifications identified in Albufera de València lagoon sediments. Aquat. Bot. 92, 14-22.

Rodrigo, M.A, Rojo, C., Alonso-Guillén, J.L., Vera P., 2013a. Restoration of two small Mediterranean lagoons: the dynamics of submerged macrophytes and factors that affect the success of revegetation. Ecol. Eng. 54:1-15.

Rodrigo, M.A., Martín, M., Rojo, M., Gargallo, S., Segura, M., Oliver, N., 2013b. The depurative role of two small man-made Mediterranean lagoons in the context of a broader remediation system: effects on water chemistry and plankton contribution. Ecol. Eng.

Rojo, C., Rodrigo, M.A., 2010. Plankton ecology and diversity. pp: 137-173. In: Ecology of threatened semi-arid wetlands. Long-term research in Las Tablas de Daimiel. Eds: S. Sánchez-Carrillo \& D.G. Angeler. Springer.

Rojo, C., Álvarez-Cobelas, M., Benavent-Corai, J., Barón-Rodríguez, M.M., Rodrigo, M.A., 2012. Trade-offs in plankton species richness arising from drought: a long- 
term study in a National Park wetland (Central Spain). Biodivers. Conserv. 21, 2453-2476.

Rojo, C., Segura, M., Rodrigo, M.A., 2013. The allelopathic capacity of submerged macrophytes shapes the microalgal assemblages from a recently restored coastal wetland. Ecol. Eng. DOI 10.1016/j.ecoleng.2013.06.019.

Scheffer, M., Hosper, S.H., Meijer, M.L., Jeppesen, E., Moss, B., 1993. Alternative equilibria in shallow lakes. Trends Ecol. Evol. 8, 275-279.

Scheffer, M., Rinaldi, S., Gragnani, A., Mur, L.R., Van Nes, E.H., 1997. On the dominance of filamentous cyanobacteria in shallow, turbid lakes. Ecology 78, 272282.

Schneider, S., Ziegler, C., Melzer, A., 2006. Growth towards light as an adaptation to high light conditions in Chara branches. New Phytol. 172, 83-91.

Smolders, A.J.P., den Hartog, C., van Gestel, C.B.L., Roelofs, J.G.M., 1996. The effects of ammonium on growth, accumulation of free amino acids and nutritional status of young phosphorus deficient Stratiotes aloides plants. Aquat. Bot. 53, 8596.

Wuestenberg, A., Pors, Y., Ehwald, R., 2011. Culturing of stoneworts and submersed angiosperms with phosphate uptake exclusively from an artificial sediment. Freshw. Biol. 56,1531-1539. 


\section{Legends to figures}
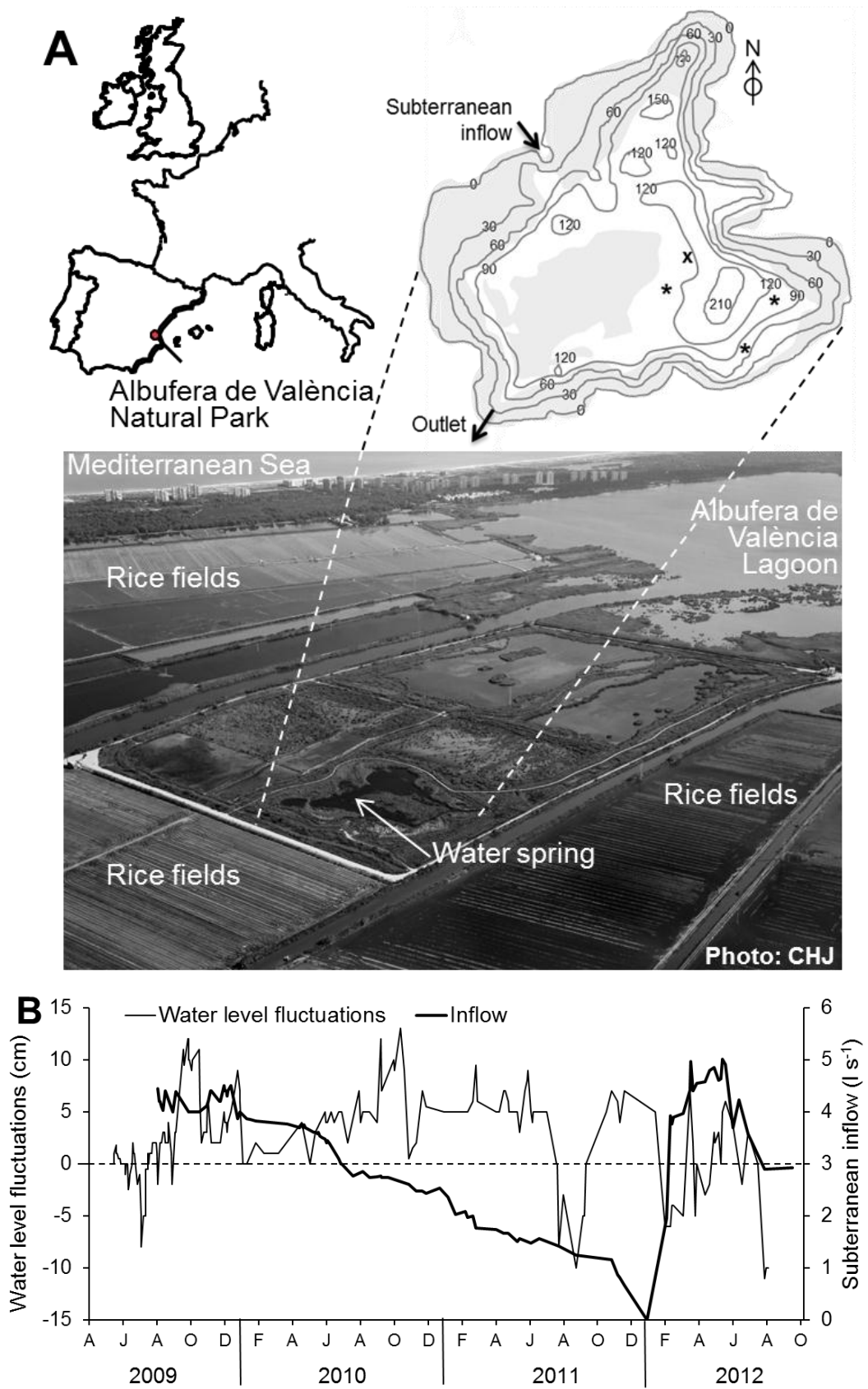

Fig. 1. A: Location of the study site, including a morphometric map of the water spring indicating the sampling sites (charophyte and water sampling sites are indicated by asterisks and an $\mathrm{x}$, respectively). The groundwater inflow and the outlet are also shown. Isolines indicate water depth $(\mathrm{cm})$. The grey area indicates helophyte cover. $\mathrm{B}$ : Time course of the groundwater inflow and the water level fluctuations in the water spring (referred to the 0 water depth on the day the pole was set up) during the study period. 

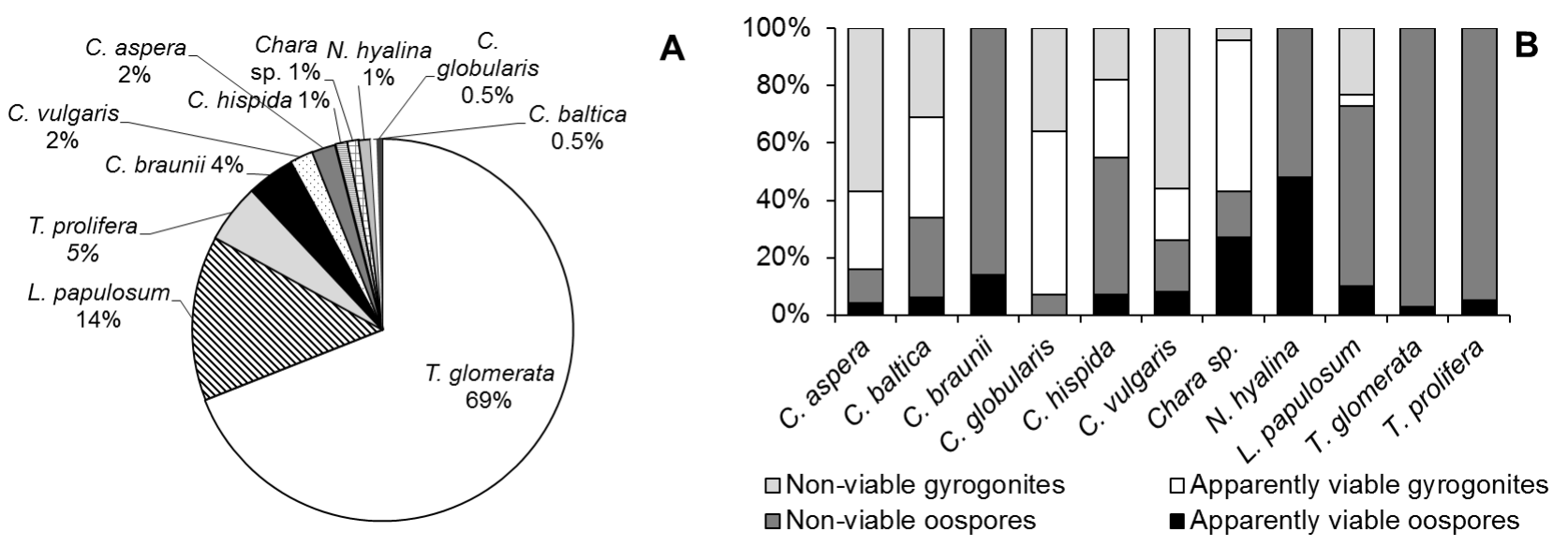

Fig. 2. A: Percentage of charophyte fructifications found in the sediments of the water spring in 2008 (after flooding the basin). B: Apparent viability percentages of these reproductive structures. 

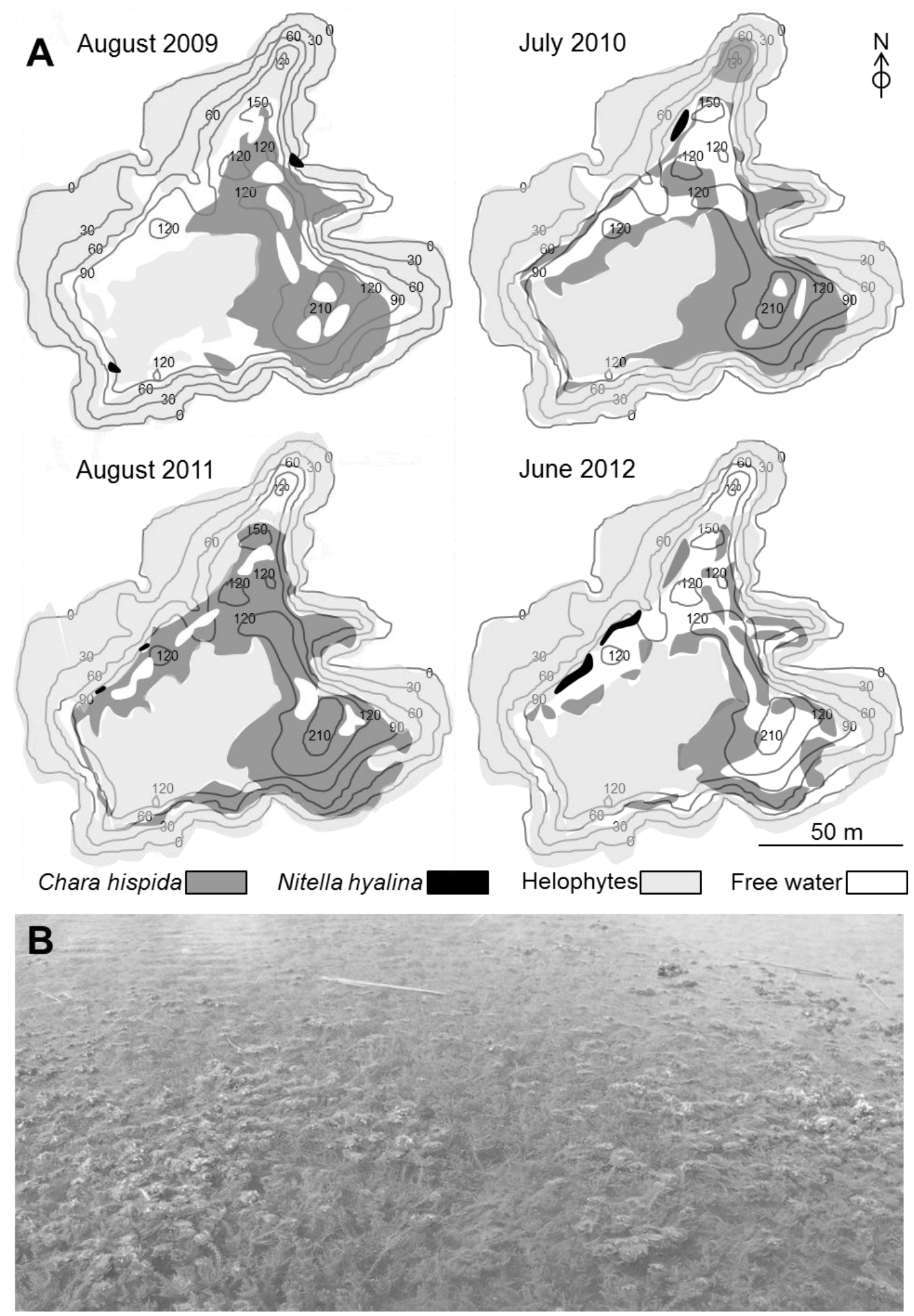

Fig. 3. A: Maps of vegetation cover in the water spring in the summers of 2009-2012. Isolines indicate water depth $(\mathrm{cm})$. B: Photograph of the $C$. hispida meadow at the water surface in June 2010. 

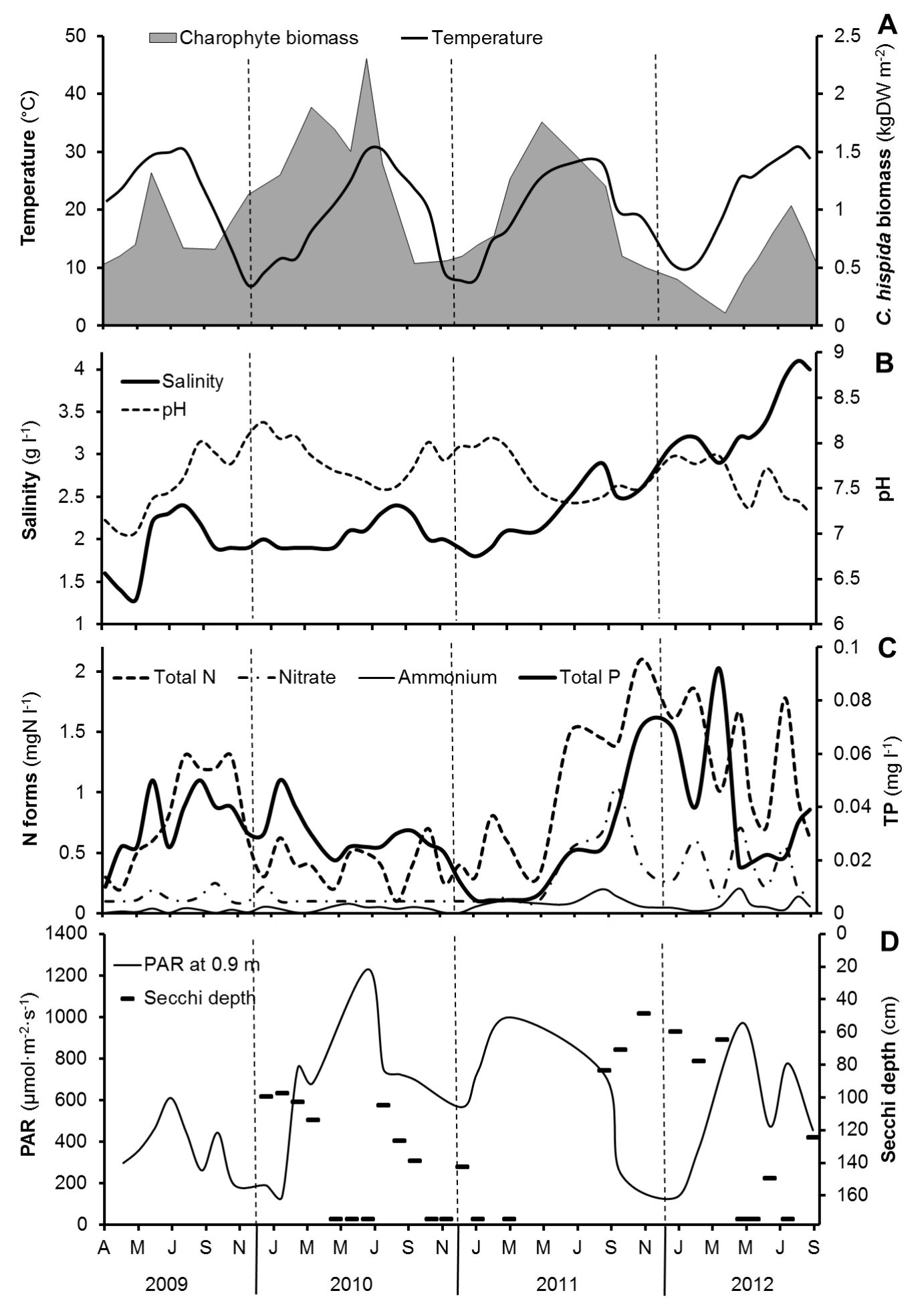

Fig. 4. Dynamics of water temperature (C. hispida biomass represented by the shadowed area), $\mathrm{pH}$, salinity, $\mathrm{N}$ forms, TP, irradiance (PAR) at a depth of $90 \mathrm{~cm}$ and Secchi disc depths $(->160 \mathrm{~cm}$ indicates the Secchi disc could be observed all the way to the bottom) in the water spring. 

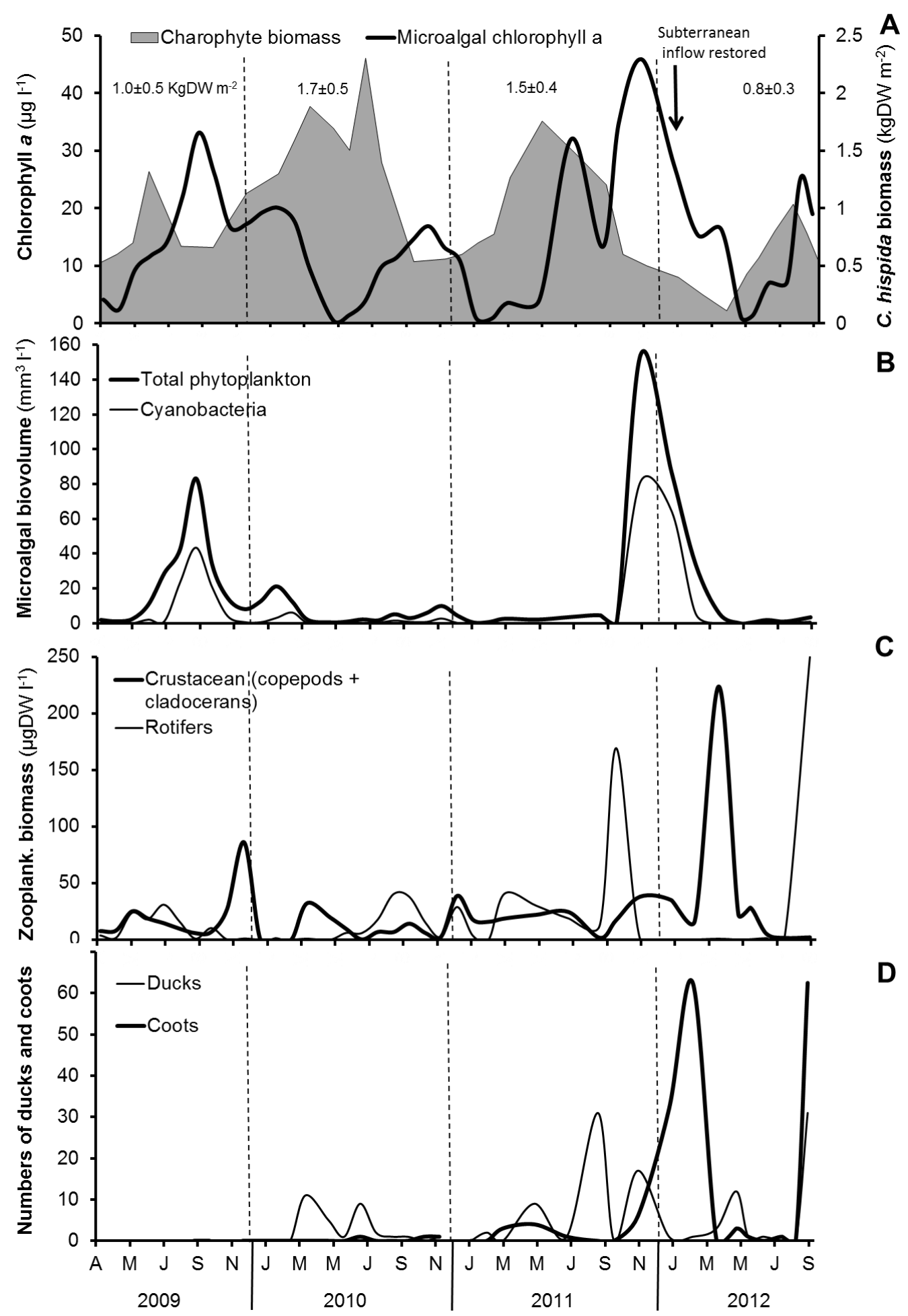

C

D

Fig. 5. Dynamics of $C$. hispida biomass per surface unit (the numbers indicate mean \pm standard deviation during the warm periods), microalgal $\mathrm{Chl}$ a, phytoplankton biovolume, cyanobacteria biovolume, zooplankton biomass (rotifers and crustaceans: copepods + cladocerans) and numbers of herbivorous waterfowl in the water spring. 

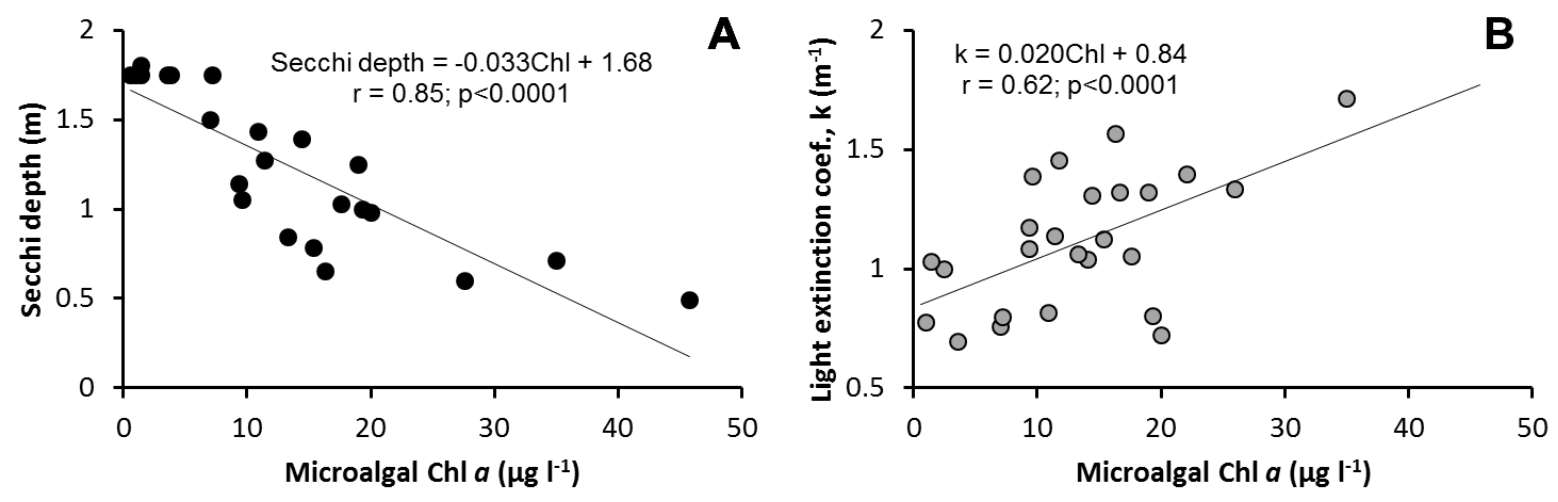

Fig. 6. Relationships between microalgal $\mathrm{Chl}$ a concentration and Secchi disc $(\mathrm{A})$ and light extinction coefficient (B; calculated for the first half meter of depth) in the water spring. 
Table 1. Vegetation coverage $\left(\mathrm{m}^{2}\right)$ and total $(\mathrm{Kg} \mathrm{DW})$ biomass of charophytes in the water spring in the summers of four consecutive years (July-August except for 2012, when June was the studied month). The coverage of helophytes (primarily Typha spp. and Phragmites spp.) is also indicated.

\begin{tabular}{cccccccccc}
\hline & \multicolumn{2}{c}{2009} & \multicolumn{2}{c}{2010} & \multicolumn{2}{c}{2011} & \multicolumn{2}{c}{2012} \\
\cline { 2 - 9 } & Cover $\begin{array}{c}\text { Total } \\
\text { biomass }\end{array}$ & Cover $\begin{array}{c}\text { Total } \\
\text { biomass }\end{array}$ & Cover $\begin{array}{c}\text { Total } \\
\text { biomass }\end{array}$ & Cover $\begin{array}{c}\text { Total } \\
\text { biomass }\end{array}$ \\
\cline { 2 - 9 } Chara hispida & 4,644 & 3,111 & 5,326 & 12,185 & 6,378 & 7,684 & 3,125 & 1,781 \\
Nitella hyalina & 2 & 0.2 & 34 & 22 & $<1$ & -- & 70 & 12 \\
Helophytes & 12,378 & -- & 12,408 & -- & 12,590 & -- & -- & -- \\
\hline
\end{tabular}

